$\xi=-1$

\title{
Risks and Threats Posed to a Company's Economic Security
}

\author{
Sergey Valeryevich Bank1, Vladimir Dmitriyevich Sekerin1, Anna Evgenievna Gorokhova1, Nikolay Ivanovich Ni- \\ kolaykin2, Anton Gennadievich Shcherbakov3
}

\author{
1Moscow Polytechnic University, 38 Bolshaya Semenovskaya St., Moscow, 107023, Russia \\ 2Moscow State Technical University of Civil Aviation, 20 Kronstadt Blvd., Moscow, 125993, Russia \\ 3ASPI Group, 26 Stroginsky Blvd., Bldg. 2, Ste. 341, Moscow, 123592, Russia
}

\begin{abstract}
This paper examines some of the major types of risks and threats that may be posed to the economic security of national enterprises. Its purpose is to terminologically fine-tune the categories 'threats' and 'risk', analyze and classify risks from the standpoint of the multicriteria approach, as well as fine-tune existing methods for assessing risks faced by a firm's economic security system. Based on the findings from their analysis of relevant materials, the authors have formulated the following conclusions:

- an event that does not yield itself to assessment from the standpoint of quantitative and qualitative parameters is regarded as a threat. In this context, it becomes virtually impossible to come up with efficient preventive activities, as it is problematic to conduct quantitative assessments of this kind of event. Reducing the extent of a threat requires identifying and classifying relevant risks;

- a modern enterprise is a backbone element in the national economy. Managing risks and threats posed to economic security at the microlevel is a part of the national strategy for social/economic development in the Russian Federation. This is why threats that emerge at the level of interaction among business entities are strategic risks;

-assessing risk implies not only identifying the intensity of negative impact factors but constructing its specific forms as well. Assessment procedures are based on detecting negative impact factors, establishing the degree of their impact on a firm's economic security system, and forecasting the potential reactions of the firm's subsystems. The most frequently used assessment methods are expert and mathematical methods.
\end{abstract}

Keywords: economic security, threats, legal risk, criminal risk, competitive risk, counterparty risk, firm's production potential.

\section{Introduction}

The complexity of structural interrelationships and the multicomponent nature of external environmental factors necessitate the development of a firm's economic security system to help reduce their negative impact. Analyzing and classifying risks and threats posed to activity, as well as assessing the significance and degree of impact on a firm's performance, are a necessary condition for providing appropriate countermeasure activities and putting in place the firm's economic security system.

Russia's present-day economic system is characterized by complex structural interrelationships and low levels of forecastability with respect to the situation in the market. An additional negative factor is the active use of methods of unfair competition by business entities. Special significance is being taken on today by activities aimed at ensuring economic security.

The 'economic security' category started to be employed in economic theory and business practice in the first half of the $20^{\text {th }}$ century. The need to develop integrated activities aimed at ensuring security was predetermined not only by parameters for the internal structure of economic systems but by the cyclicity of their development as well.

Economic security systems may be considered to have two levels to them: the level of the economic system as a whole and the level of the business entity [1]. The literature offers a comprehensive roster of construals for the term 'a firm's economic security'. This category may be viewed from the standpoint of the re- source/functional approach, which deals with the effective use of a firm's resources. Also, a firm's economic security may be regarded from the perspective of the organizational approach, whereby the operation of all subsystems within the firm is geared to the realization of potential for ensuring competitive advantage. The systemic approach implies a combination of the above viewpoints, which helps ensure comprehensive protection for all types of the firm's assets and realization of its economic interests.

The effectiveness of a firm's economic security system is determined by how correctly one can identify threats and risks. The integrated nature of the impact of negative factors substantiates the need to classify them factoring in multicriteriality.

\section{Methods}

The study's theoretical basis is grounded in some of the key tenets of economic theory, public administration, as well as in the research by foreign and domestic scholars into issues in strategic management, economic security, risk management, and analysis of internal and external environmental market factors. The work is supplemented with methodological insights in the area of managing risks and threats posed to economic security, as well as materials from specialized literature and periodic publications.

The study's methodological basis incorporates the use of methods of scientific cognition, including factor and system analysis of the economics and processes of management. From the standpoint of factor analysis, investigating into processes of risk and threat management implies detecting the conditions for the activization 
of and establishing the extent of impact from the more significant parameters for the environment surrounding the entity. The systemic approach is based on the construction of an integral structure of interdependent external and internal conditions which ensure the implementation of activities related to ensuring economic security [2].

The study's information and empirical basis is grounded in the systematization of the principal concepts of managing risks and threats within a firm's economic security system. The authors also employ methods of expert assessment.

The basis of the applied research reported in this paper aimed at not just identifying threats and risks but also assessing them is integrated economic/mathematical methods for exploring systems and objects. Methods of dispersion and regression analysis, fuzzy systems theory, inclusive of cluster analysis, and methods of exponential smoothing are supplemented with methods of statistical analysis in a climate of multifactorialness. The authors do not consider as the study's objective the quantitative assessment of risks and threats, so this paper covers only the potential for using the above methods. With that said, it is apparent that the strategic management of a firm's economic security ought to incorporate the development of methodology for the integrated assessment and forecasting of impact factors, particularly threats and risks, in developing and substantiating a new approach to assessing positive and negative conditions based on the use of a firm's economic indicators as a deciding parameter for economic security. The findings may be viewed as a part of a firm's anti-crisis strategy.

\section{Results}

A summarization of the findings from exploring the substantive characteristics of the category 'a firm's economic security' has helped identifying two major approaches to this phenomenon [3]. On the one hand, a firm as an object is viewed as an integrated system, the major characteristic of which is the availability of the more significant structural parameter which determines the orientation of the object's operation. The system's openness to external and internal factors predetermines the existence of threats and dangers that form risk factors, which requires the development and implementation of activities on preventing negative impact on the system's crucial elements. Under this approach, crucial criteria are structural characteristics. On the other hand, an enterprise is not a static system, and the dynamics of its development are substantiated by the need to achieve set objectives. Counteraction on the part of external and internal environmental factors complicates the achievement of objectives. Proposing a set of activities that help eliminate or counterbalance the impact of these factors may too be viewed as a measure aimed at ensuring an object's economic security. Common is focusing attention on the high degree of dependence on the impact of external and internal factors, mostly viewed as threats and risks [4].

The present-day theory of technogenic risk defines 'risk' as the likelihood of a danger materializing factoring in the size of its aftermath (above all its economic consequences) [5]. The literature contains a view whereby, in analyzing dangers of the technosphere that arise as a consequence of deliberate actions by people (organizations) intended to purposefully inflict some kind of damage (e.g., aggression, terrorism, vengeance, etc.), one may use the term 'threat', considering it a synonym of the term 'danger'. For instance, quite unequivocal is the use of the term 'a threat to transportation security', which deals with the concept of Russia's transportation security. With that said, 'danger' is viewed as the propensity of man and the environment which determines the possibility of inflicting damage to living and nonliving matter.

A firm's economic security is closely associated with ensuring the environmental security of its activity. Thus, for instance, one of the major global challenges to the development of present-day civil aviation is the mismatch between current increases in air passenger traffic and the requirement to reduce aviation's envi- ronmental impact on the biosphere [6]. This is characteristic of many sectors of the economy.

Today's economic literature makes no clear distinction between the categories 'risk' and 'threat'. Certain researchers view these terms as synonymous [7].

Threats to a firm's economic security are viewed as existing social/economic, statutory, and other factors that impact its economic security in various time intervals. With that said, the nature of impact will be assessed as negative. Among the key sources of negative impact is the nature of interaction among economic entities, as well as market-determined characteristics at the macroand microlevel.

Interpreting threats in a negative light is fundamental. On the whole, the authors are not proposing the use of a single characterization of threats, but are suggesting that the phenomenon be considered in a substantive manner from the perspective of the characteristics of negative impact [8].

Thus, for instance, in the dictionaries by Ozhegov and Ushakov the terms 'danger' and 'threat' have similar meanings. Certain authors characterize a threat through a danger that is of an objective nature. The scenaric approach draws a distinction between the terms 'threats' and 'risks'. With that said, viewed as a determining parameter is the possibility of conducting quantitative and qualitative assessments of events.

A threat is construed as an event of a negative nature that does not lend itself to quantitative and qualitative assessment due to that the firm, as an entity, may have not come across this kind of events before. Due to the impossibility of assessing an event, anticipatory measures cannot be regarded as efficient a priori. To help minimize a threat, relevant risks are identified and classified, which helps formulate a roster of relevant preventive activities. Thus, analysis of threats is a component of the process of analyzing risk. Therefore, characterizations of threats become relevant after risks have been determined and classified.

Generally, the category 'risk' is construed in the domestic and foreign literature as a situation in which there exists a high degree of likelihood of unknown events occurring, with it being possible to assess this likelihood quantitatively $[9,10]$. Conditions in which quantitative assessments are impossible are characterized as uncertainty. Risk may be characterized from the standpoint of the situational approach, using assessment theories, viewed as a function, or via factor analysis.

Under the situational approach, risk is viewed as a situation that is characterized by uncertainty in terms of how to resolve the problem, and its outcome can both be positive and negative for the firm. The level of uncertainty may be correlated with assessments of the likelihood of expected events occurring, which is what implies the use of the assessment approach to investigating risks. A positive effect or a negative one is the result of certain actions and certain functions executed with preset parameters. This forms the basis of the functional approach. Risk factors are potential conditions that determine the potential for achieving an objective or the possibility of deviating from it, which are investigated under the factor approach.

The economic literature offers a variety of approaches to investigating risks $[11,12]$. With the development of the market and entrepreneurship, the term 'risk' was moved into a separate category back in the second half of the $19^{\text {th }}$ century. The issue of risk management received further development in works by K. Arrow, $\mathrm{H}$. Markowitz, as well as representatives of the neo-institutional strand of economic science.

Issues of risk management have been investigated by Russian economists as well $[13,14]$. Between the 1920 s and 1930s, the government passed a number of statutes that formulated the actual concept of economic risk. Today's Russian economic science and entrepreneurship theories offer a plethora of approaches to the substantive assessment of the categories 'risk' and 'security'. Particularly worthy of mention are works by V. Abchuk, I.Balabanov, L. Blyakhman, V. Glazunov, A. Ivasenko, D. Morozov, E. Utkin, and V. Chernov. The theoretical/methodological basis for research 
into the subject is grounded in works by prominent foreign economists such as J. Galbraith, F. Kotler, R. Coase, J. Lafta, P. Lindert, D.H. Meadows, D.L. Meadows, J. Randers, M. Porter, O. Williamson, J. Schumpeter, M. Goldberg, D. Forbush, and A. Thompson [15].

Research into factors of risk and risk situations involves the use of the integration approach, which implies the use of a methodological apparatus of adjacent sciences. More specifically, scholars I. Bizyukov, V. Goncharov, G. Diligenskii, A. Kochetkov, N. Litvintseva, and J. Humphries have drawn upon some of the basic tenets of conflictology.

Factor analysis of risks helps identify their major types, which are determined either by the nature of information or based on technology for selecting it. This approach has been employed in works by V. Diev, A. Movsesyan, G. Myrdal, R. Nizhegorodtsev, A. Rakitov, M. Rassolov, A. El'yanov, and E. Jeffrey [16].

Competitive analysis of research into the nature of risks has found reflection in works by M. Porter and S. Huntington. Issues of regional security and political risks have been investigated in works by A. Vladimirov, V. Gal'perin, P. Grebennikov, E. Kochetov, A. Leusskii, Yu. Lipsits, L. Tarasevich, and S. Schlichter [17].

Scholar A. Romanyuk has drawn upon a number of specialized sources to analyze the characteristics of the term 'risk' in relation to the microeconomic level, which has led to the conclusion that 'risk' correlates with 'danger' in a climate of uncertainty which implies its probable emergence.

This view is currently prevalent in research into negative impacts on the state of economic security. With that said, apart from risks negative impacts also incorporate dangers, challenges, threats, and shocks.

\section{Discussion}

Investigating the genesis of risks and threats posed to a firm helps identify their social, technogenic, and natural basis. Social factors predetermine the existence of political and economic (commercial) risks. Technogenic risks are associated with the conditions for a firm's operation, implying danger linked with the execution of work and utilization of the firm's resources. Natural factors, under which one subsumes ecosystem parameters, lend themselves the least to influence on the part of economic security system. There are also legal, criminal, competitive, and counterparty risks [4].

Conditions and factors that are pregnant with danger may either emerge on their own or do so under the influence of certain circumstances. A common feature of risks and dangers is their destructive nature and the negative nature of their impact on a firm's subsystems. The multiplicity of classification criteria substantiates the need to develop a set of relevant preventive activities that would help eliminate or counterbalance the negative impact of threats and risks considered [18].

The first group of criteria is formed based on the existence of potential for impacting on risks and threats. In this respect, it may be worth identifying the following:

- $\quad$ foreseeable (predictable) and unforeseeable risks and threats;

- $\quad$ objective and subjective risks, which are differentiated from the standpoint of interaction among business entities;

- $\quad$ force majeure and nonforce majeure risks, which are characterized as threats that either lend themselves or do not lend themselves to action;

- $\quad$ insured risks and noninsured risks transferred to external organizations, on which it is impossible to determine effective countermeasures;

- $\quad$ pure and speculative risks, which reflect the substantive characteristics of entrepreneurial activity and interpreting which helps determine the existence only of threats or potential for gaining an additional win.
In classifying objects of managerial action, risks may be identified based on the types of corporate resources. Objects' being of a limited or an integrated nature help identify plain risks, risks that cannot be broken down into separate elements, and integrated risks.

From the standpoint of measurability of risks and threats, the following may be identified:

- $\quad$ catastrophic, substantial, and destructive factors which cause difficulties;

- latent, hard-to-detect, and apparent dangers which really

exist;

- long-term, short-term, and current risks, which are divided based on the time parameter;

- temporary risk, which emerges at certain stages in a firm's activity, and permanent risk, which is characteristic of the entire period of operation.

The equivocal nature of sources of risks and threats leads one to classify risks based on the area of emergence of threats [19]: global and private risks, which are characterized based on the level of localization of sources of their emergence and the degree to which one is exposed to the consequences;

- $\quad$ spatial risks, the basis for differentiating which is grounded in the territorial factor;

external and internal environmental risks, which are determined by the conditions of a firm's micro- and macroenvironment;

- $\quad$ production, commercial, and financial risks, which are identified based on the types of the firm's activity.

Classifying risks based on the criteria selected helps to identify the sources of threats and dangers and determine those that are most significant to a firm's activity, as well as establish the potential for impacting on the negative factors identified. Concurrently, one can conduct both quantitative and qualitative assessments of risks and threats to the firm's economic security.

A modern enterprise is a backbone element in the national economy. The management of risks and threats to economic security at the microlevel is a part of the national strategy for social/economic development in the Russian Federation. That is why threats that emerge at the level of interaction among business entities are strategic risks [20].

Quantitative assessments of threats to the activity of national enterprises help define them as strategic risks. The indicators reflect the degree to which the enterprise depends on macroenvironmental factors, and thereby substantiate the existence of threats to the economic security of the Russian economy.

Apart from macroeconomic indicators and their threshold values, the Center for Financial/Banking Research of the Economics Institute of the Russian Academy of Sciences has also formulated a set of sectoral level indicators, which include parameters for the performance of national enterprises, including factors that determine the effectiveness of their operation. Key values are indicators of investment activity and the innovation activity of enterprises. Research indicates that on these crucial parameters the economy is in a danger zone, i.e. the level of threat to national economic security is quite high.

The Russian economy continues to be focused primarily on the fuel and raw materials export model of development, with insufficient attention given to the use of scientific/technical and technological innovations, which is impeding boosts in the productivity of enterprises.

Russia's national enterprises are still exhibiting low competitiveness levels, which is affecting their market positions both domestically and in the global markets. The expansion of imported goods within the B2B and D2C (G) sectors against a backdrop of the low competitiveness of products turned out by Russian manufacturers is giving rise to market threats in both the Russian and foreign markets.

Note also the significant dependence of entrepreneurial establishments in practically all sectors and spheres of the Russian econo- 
my from external economic conditions, as well as on economic and political decisions made by integrated transnational conglomerates, international organizations, and global trade blocs. Letting it go beyond the limits of openness of the national economic system is augmenting the impact of international organizations on Russian business entities, which is putting national enterprises at a major disadvantage.

Russia's current recessionary economic conditions are making it impossible to secure reserves of production capacities and resources of all kinds. High levels of uncertainty and the impossibility of forecasting production and sales in the Russian markets are also reflecting on the planning of production processes and resource support for them. Physical and moral wear and tear in enterprises is a threat to the nation's economic security. On the one hand, this predetermines the technical and technological backwardness of enterprises, while, on the other hand, it amplifies financial risks due to increases in expenditure on the upkeep of plant and equipment, which is part of the prime cost of products turned out by the enterprise.

Indicators of the specific output of the machine manufacturing and metalworking sectors exhibited a trend toward declining during the preceding periods in the development of the Russian economy. The share of output from the above sectors dropped to $20-22 \%$, and that is considering that the threshold value of $25 \%$ is an indicator of economic security at the sectoral level [21].

Declines in the production potential of enterprises currently operating in Russia are due to low investment activity. This poses a tangible threat to companies' economic security, which is predetermined, on the one hand, by a lack of financial resources and, on the other hand, by Russia's imperfect legislation. In the period 2008-2015, investment in fixed assets, especially within the material production sector, declined almost by a fourth of its total volume.

Investment is needed the most by sectors concerned with the manufacture of consumer goods. The proper organization of domestic production of mass consumer goods is currently a top priority for the Russian economy for two major reasons: firstly, there is a need to create competitive sectors, and, secondly, there is a need to reduce the nation's dependence on foreign manufacturers, which is being done at the moment via import substitution programs pursued by the Russian government.

Today, extremely low volumes of investment are being infused into the nation's agriculture and light industry, as well as hightech venture capital sectors and scientific/technical spheres. With that said, their share in the overall volume of foreign investment does not, normally, exceed $0.1-0.4 \%$.

Russia's current monetary situation is fairly unstable, which, on the one hand, is due to failure to fulfill one's obligations, and, on the other hand, due to the tough policy of regulating the activity of financial institutions pursued at the moment by the Central Bank of Russia.

Russia's current, fairly destimulating, fiscal policy is fraught with decreased business activity and an unfavorable entrepreneurial climate. On the one hand, this may lead to a slowdown in the growth and development of the SME segments, which especially is of relevance for Russia's regions, while, on the other hand, a shrinking of the private entrepreneurial sector may result in declines in revenue coming into the country's federal and local budgets. On the whole, this may have negative impact on economic growth, ensuring which is an objective of a strategic nature [22] Russia's current market-related characteristics - above all, people's paying capacity - are having negative impact on consumer demand, for which reason they may be viewed as a factor of threat to the economic security of Russia's national enterprise. The nation's differentiation in revenue, which is another major characteristic of today's Russian economy, is characterized by a highly pronounced territorial attribute: income gaps between urban and rural residents have reached $25-40$ times. Over 30\% of Russians earn today less than the minimum subsistence level.
A crucial component of a firm's market activity is the logistics subsystem - more specifically, work with suppliers and contractors. The existence of an aggregate of threats to economic security is due to failure on the part of partners, ordering parties, suppliers, clients, and other participants in economic interaction to make good with regard to fulfilling the contract terms, making the payments, or supplying the goods.

Today's economic/legal factors that determine the performance of enterprises within Russia's present-day economy can hardly be viewed as a stimulus for the development of the nation's private business sector. On top of that, on a number of aspects the current state of the nation's legal environment and its current infrastructure parameters may be posing a serious threat to the economic security of most enterprises. In particular, high levels of corruption among officials, which, among other things, are caused by the nation's imperfect legal framework, are coupled with wanton allegations of irregularities on the part of control and oversight institutions.

Based on an analysis of structural changes currently taking place in the Russian economy, the technical and technological lag of Russia's industrial enterprises behind their foreign counterparts has lately increased from $10-15$ to $20-25$ years. Declines in the share of production enterprises among all enterprises operating within the industrial production sector of the national economy have given rise to issues in staffing - more specifically, declines in personnel's professional/qualification levels as a result of the need for industrial/production personnel reducing by almost a third. This, in turn, has resulted in drops in production competitiveness levels and declines in the competitiveness of products turned out. Given that outmoded technological equipment is still being used, there is another threat to economic security that is emerging - lack of industrial/production personnel, above all well-qualified specialists. In addition, there are declines across all areas of sciencedriven activity: design and engineering, production and assembly of equipment related to automated monitoring (control), communication, and management; production information systems and integrated management and control systems. There are declines in the number of progressive production processes in the area of automation of loading and unloading operations and transportation of materials and parts, which is causing declines in the competitiveness of domestic manufacturers in this area of activity as well [23].

In the period 2000-2015, the share of design and design-andsurvey organizations in the overall number of organizations operating within the sphere of research and development dropped nearly five times. The total number of organizations offering progressive production technology for implementation reduced by nearly a third, while the number of created progressive production processes declined by almost a fourth. The number of design centers and design-and-survey organizations continues to decline, worsening the prospects for new products and technologies, which otherwise could help ensure comparable levels of competitiveness, emerging in the innovation market.

Risk as an existing situation and a factor for a firm's economic development may have both negative impact and positive one. It is also worth admitting that the impact of risk factors may have a neutral outcome. An issue that requires working out and making proper managerial decisions is the likelihood of a negative outcome in each stage of a firm's activity [4].

Negative impact factors are seen as existing conditions, the impact of which on the economic system may result in damage. The likelihood of economic losses being incurred and their size are viewed as key negative characteristics within the economic security system. This system's key focus is on not only identifying but also differentiating risks and threats from the standpoint of the different levels of impact. Therefore, the category of the likelihood of negative events occurring and negative outcomes arising is viewed as the key interest focus in designing an economic security system. 
Since risk is a probabilistic category, it should be possible to quantitatively assess the possibility of incurring a loss. Researchers have suggested that on an assessment scale of 0 to 1 the likelihood of incurring a loss expressed in values from 0.3 to 0.5 should be suggestive of a risk, and if it is expressed in values from 0.7 to 0.9 it should be suggestive of a threat. A threat-forming risk is characterized by an interval value from 0.5 to 0.7 . This means that impact factors are characterized by a pronounced negative trend that is not viewed as obvious as yet [24].

The process of determining the degree of impact of expected outcomes of a negative nature on a firm's performance is viewed as assessing risk. Assessing risk implies not only determining the intensity of impact but constructing its specific forms as well. The assessment procedure may include the following stages:

- $\quad$ detection of negative impact factors;

- $\quad$ identification of the vector of development of impacting conditions on the firm's performance indicators;

- development of possible reactions by the firm as a system under the impact of factors of risk and threats.

Threats and risks posed to a firm's economic security are assessed using various methods, with preference given to methods of mathematical modeling and mathematical analysis, as well as the expert assessment method.

The use of mathematical methods requires a special command of the mathematical apparatus and proper potential for employing it in the existing conditions. Also, the use of this methodology implies collecting a significant amount of information, which may be subjected to statistical processing. In the practice of management and economic analysis, economists and individuals in charge of a firm and those in charge of its divisions may face difficulties with obtaining and processing this type of information [25].

The authors view expert assessments as a practicable method that perfectly lends itself to the process of analyzing probabilistic models. The method implies collecting, analyzing, and assessing the views of independent experts, which subsequently becomes the basis for managerial decision-making. Independent experts normally include leading specialists in the area or those focused on investigating the specific issue in question.

Expert assessments may contradict each other, which is why a crucial factor for the method's objectiveness is the consistency of assessments. The task group must work out an assessment scale that would help develop a quantitative characterization of the likelihood of negative events occurring and assess the significance of relevant risk and threat factors.

Should there be detected discrepancies among the experts' views (i.e., if the established rules have failed), it may help to discuss them with the experts in more detail. If no discrepancies have been detected, one can go on to compute the arithmetic mean value of the likelihood of negative events occurring, which subsequently is used in conducting the procedure of assessing the impact of negative factors.

Expert assessments incorporate characterizations of both external and internal environmental factors. Assessments of external factors of both a regulated and unregulated nature include the social/political and economic situation, the legal environment, the degree of being provided with resources of all types, current conditions in the market, and the availability and operation of infrastructure [26].

Of importance are also characterizations of actual participants in economic activity: partners, competitors, counterparties, and suppliers. Due to the growing frequency of the use of methods of unfair competition, which by definition are more effective, it is worth considering factors such as the reliability, financial sustainability, and business reputation of participants.

Assessments of external environmental factors are supplemented with characterizations of the firm's internal parameters and economic security system. Characterizations of parameters of the internal environment are carried out on all levels of the subsystem and include describing all types of corporate resources. Each of the resources considered is by itself an economic security risk factor.

\section{Conclusion}

To summarize the materials and analytical information examined in this paper, the following conclusions could be formulated:

Today's theory and existing practice of managing an enterprise draw no confirmed substantive distinction between the categories 'risk' and 'threat'. The term 'threat' comes up when classifying risks as part of the scenaric approach.

- The economic security system in Russian enterprises is predicated on the tenets of the risk management concept, with analysis of risks and threats and their classifications being the determining stage in the process. The multicriteria nature of the qualitative characteristics of risks faced by national enterprises makes it possible to structurize and systematize risk factors as part of the development of programs for ensuring economic security.

- Threats and risks are managed at the microlevel as a part of strategic management of business entities within the sectors and subsectors of the national economy. Therefore, ensuring a firm's economic security is a part of anti-crisis programs for the economy of the Russian Federation.

- Qualitative assessments of risks and threats imply substantive descriptions of factors that trigger them. Quantitative assessments imply assessing the degree to which each of the factors considered influences, as well as their integrated impact on, the firm's subsystems.

- Given the existing diversity of methods for assessing risks and threats, the widest use is made of methods of mathematical analysis and expert methods. The use of the above methodology is based on the analysis of large arrays of information, including statistical information.

- $\quad$ This paper did not aim to calculate real economic indicators using mathematical, statistical, and expert methods. Risks and threats posed to economic security were analyzed and classified at the level of business entities. The issue of systemic interaction at the sectoral level has yet to be explored in due detail. The objectives examined in this paper may be given greater attention in subsequent theoretical and applied research devoted to issues of the economic security of business entities within the Russian economy.

\section{References}

[1] V.V. Ploshkin, Otsenka i upravlenie riskami na predpriyatiyakh: Uchebnoe posobie [Assessing and managing risk in an enterprise: A study guide]. TNT, Stary Oskol, 2013.

[2] J. Jorion, Financial risk manager handbook, Wiley, Hoboken, 2009.

[3] G.V. Fedotova, Upravlenie riskami v innovatsionnoi deyatel'nosti predpriyatii [Risk management within a company's innovative activity], Finansy i Kredit 41 (2010) 27-33.

[4] J.J. Fay, Contemporary security management, ButterworthHeinemann, Burlington, 2011.

[5] Yu.G. Khudyakov, N.I. Nikolaikin, Vidy riskov i osobennosti ikh proyavleniya $\mathrm{v}$ aviatransportnoi usluge, predostavlyaemoi aviakompaniei [The various types of risks and some of the characteristics of their manifestation in relation to an air transportation service provided by an airline], Nauchnyi Vestnik Moskovskogo Gosudarstvennogo Tekhnicheskogo Universiteta Grazhdanskoi Aviatsii 149 (2009) 7-13.

[6] A.I. Ivanov, N.I. Nikolaikin, Formirovanie proizvodstvennykh brigad dlya povysheniya ekologicheskoi bezopasnosti [Forming production teams to boost environmental security], XXI Vek: Itogi Proshlogo i Problemy Nastoyashchego Plyus 7(2) (2018) 43-49.

[7] G.D. Kapanadze, Finansovaya ustoichivost' kak klyuchevoi element ekonomicheskoi bezopasnosti kompanii [Financial sustainability as a key element in a company's economic security], Rossiiskoe Predprinimatel'stvo 22 (2012) 10-16. 
[8] W.B. Nixon, K.M. Kerr, Background screening and investigations: Managing hiring risk from the HR and security perspectives, Butterworth-Heinemann, Oxford, 2008.

[9] S.S. Golubev, S.S. Chebotarev, Effektivnaya strategiya upravleniya riskami kak osnova ekonomicheskoi bezopasnosti banka [An effective risk management strategy as the basis for a bank's economic security], Ekonomicheskie Strategii 19(3) (2017) 186-195.

[10] V.N. Batova, A.Yu. Pavlov, Ekonomicheskaya bezopasnost' biznesprotsessov v usloviyakh realizatsii kontseptsii ustoichivogo razvitiya [The economic security of business processes amid the implementation of the sustainable development concept], Rossiiskoe Predprinimatel'stvo 23 (2014) 113-119.

[11] D.V. Domashchenko, Yu.Yu. Finogenova, Upravlenie riskami v usloviyakh finansovoi nestabil'nosti [Managing risk in a climate of financial instability], INFRA-M, Moscow, 2010.

[12] J.D. O'Gara, Corporate fraud: Case studies in detection and prevention, Wiley, Hoboken, 2004

[13] S.N. Vorob'ev, K.V. Baldin, Upravlenie riskami v predprinimatel'stve [Entrepreneurial risk management], Dashkov i K, Moscow, 2013.

[14] A.E. Suglobov, S.A. Khmelev, E.A. Orlova, Ekonomicheskaya bezopasnost' predpriyatiya: Uchebnoe posobie dlya studentov vuzov [A company's economic security: A study guide for college students], YuNITI-DANA, Moscow, 2013.

[15] S.S. Golubev, S.S. Chebotarev, V.D. Sekerin, A.E. Gorokhova, Development of employee incentive programmes with regard to risks taken and individual performance, International Journal of Economic Research 14(7) (2017) 37-46.

[16] T.D. Giles, How to develop and implement a security master plan, Taylor \& Francis, Boca Raton, 2009.

[17] V.N. Urodovskikh, Upravlenie riskami predpriyatiya: Uchebnoe posobie [Managing risk in a company: A study guide], INFRA-M, Moscow, 2012.

[18] S.A. Filin, Risk kak element strategicheskogo upravleniya v innovatsionnoi sfere [Risk as an element of strategic management in an innovative environment], Upravlenie Riskom 3 (2010) 38-51.

[19] J.F. Broder, E. Tucker, Risk analysis and the security survey, Elsevier Science, Burlington, 2011

[20] A.M. Slinkov, K.S. Didyk, Upravlenie riskami kak faktor vliyaniya na effektivnost' deyatel'nosti organizatsii [Risk management as a factor influencing an organization's performance], Sovremennye Nauchnye Issledovaniya i Innovatsii 12 (2015) 664-666.

[21] O.V. Rossoshanskaya, Dinamicheskii kriterii otsenki ekonomicheskoi bezopasnosti innovatsionnykh proektno-orientirovannykh predpriyatii [A dynamic criterion for assessing the economic security of innovative project-oriented enterprises], Kreativnaya Ekonomika 5 (2013) 77-86.

[22] A.S. Shkarupelova, E.A. Fadeeva, Sovremennye podkhody k upravleniyu riskami predpriyatiya [The latest approaches to managing risk in an enterprise], Ekonomika i upravlenie: Problemy i resheniya (Chast' II): Materialy mezhdunarodnoi zaochnoi nauchnoprakticheskoi konferentsii (21 noyabrya 2011 g.) [Proceedings of Economics and Management: Problems and Solutions (Part 2): International Virtual Research-to-Practice Conference (November 21 , 2011)], Sibirskaya Assotsiatsiya Konsul'tantov, Novosibirsk, 2011 , pp. $133-139$

[23] A.A. Shemetev, Fundamental'nye i prakticheskie aspekty sovershenstvovaniya ekonomicheskogo mekhanizma upravleniya riskami na predpriyatii [The fundamental and practical aspects of enhancing the economic mechanism for managing risk in an enterprise], Sovremennye Nauchnye Issledovaniya i Innovatsii 5 (2013) 13.

[24] A.I. Boiko, Razrabotka sistemy upravleniya riskami malykh innovatsionnykh predpriyatii s pomoshch'yu metoda glavnykh komponent [The development of a system for managing risk in small innovative enterprises using principal component analysis] Ekonomika: Vchera, segodnya, zavtra 2 (2011) 62-75.

[25] A.S. Vasil'eva, Institutsional'naya sreda kak faktor obespecheniya ekonomicheskoi bezopasnosti [The institutional environment as a factor for ensuring economic security], Rossiiskoe Predprinimatel'stvo 15 (2012) 11-16.

[26] D. Tyson, Security convergence: Managing enterprise security risk, Butterworth-Heinemann, Burlington, 2007. 